\title{
Utjecaj reakcije tla na kationski odnos u lišću vinove loze (Vitis vinifera L.)
}

\section{Sažetak}

Reakcija tla jedan je od najznačajnijih čimbenika koji utječu na topljivost i pristupačnost hraniva biljci. Provedeno istraživanje imalo je za cilj utvrditi u kojoj mjeri reakcija tla utječe na $\mathrm{K} /(\mathrm{Ca}+\mathrm{Mg})$ u lišću vinove loze (Vitis vinifera L.), sorta Sauvignon bijeli (podloga SO4) na području Plešivičkog vinogorja (sjeverozapadna Hrvatska). Istraživanja su provedena u razdoblju 2009.-2011. godine na području Plešivičkog vinogorja na tlima jako kisele do kisele reakcije (lokacija Rečki gaj: $\left.\mathrm{pH}_{\mathrm{KCl}} 3,54-5,01\right)$ i na tlu alkalne reakcije (lokacija Borička: $\left.\mathrm{pH}_{\mathrm{kcl}} 7,01-7,41\right)$. Uzorci lišća za praćenje dinamike kalija, kalcija $i$ magnezija te njihovog međusobnog odnosa uzimani su tri puta tijekom vegetacije (fenofaza cvatnja, šara $i$ berba) u sve tri godine istraživanja. U sve tri godine istraživanja značajan utjecaj na $\mathrm{K} /(\mathrm{Ca}+\mathrm{Mg})$ odnos u lišću vinove loze imala je reakcija tla te fenofaza rasta i razvoja. Širi odnos $\mathrm{K} /(\mathrm{Ca}+\mathrm{Mg})$ u lišću vinove loze, $u$ svim godinama istraživanja utvrđen je na tlu kisele reakcije $(0,29,0,58,0,59)$ u odnosu na alkalno tlo $(0,20$, $0,40,0,38)$. Najširi kationski odnos utvrđen je u fenofazi cvatnje $(0,31-1,02)$, a najuži u fenofazi berbe $(0,15$ $0,34)$ u svim godinama istraživanja neovisno o reakciji tla.

Ključne riječi: berba, cvatnja, $\mathrm{K} /(\mathrm{Ca}+\mathrm{Mg}), \mathrm{pH}$ vrijednost, šara

\section{Uvod}

Vinova loza (Vitis vinifera L.) pripada među najstarije kultivirane biljke (Olmo, 2000), jedna je od najrasprostranjenijih voćnih vrsta u svijetu (Al-Obeed i sur., 2011) i u svjetskoj proizvodnji voća na prvom je mjestu (Pejić i Maletić, 2013). Uzgoj vinove loze u Hrvatskoj ima vrlo dugu povijest (mnogobrojni nalazi još iz prvog stoljeća prije Krista, u devetnaestom stoljeću osnovano je Hrvatsko-slavonsko gospodarsko društvo za unapređenje vinogradarstva i vinarstva, a organizirana je i Prva hrvatska izložba vina u Svetom Ivanu Zelini). U Hrvatskoj se i danas (zbog zemljopisnog položaja s vrlo povoljnim klimatskim uvjetima) uzgoja vinova loza i proizvodi vino visoke kakvoće (preko 90\% uroda prerađuje se u vino, Pejić i Maletić, 2013).

Reakcija tla jedan je od osnovnih pokazatelja plodnosti tla jer značajno utječe na topivost, a time i na pristupačnost hraniva biljci (Herak Ćustić i sur., 2005). U Hrvatskoj su vrlo rasprostranjena i kisela tla (otprilike $50 \%$ obradivih površina ima pH vrijednost nižu od 5,5 ) prema (Kovačević i sur.,1993) i alkalna tla (središnji dio istarskog poluotoka, sjevero-zapadni dio središnje Hrvatske - Plešivičko vinogorje, Gluhić i sur., 2009; kao i istok Hrvatske). Na jako kiselim i kiselim tlima smanjena je raspoloživost fosfora, kalija, kalcija, magnezija, sumpora i molibdena, a javlja se suvišak aluminija, željeza i mangana ili toksičnih teških metala, dok na alkalnim tlima previše fiziološki aktivnog vapna, također može izazvati štetu na biljkama (Bergmann, 1992) u obliku kloroza mladog lišća, kasnije pojavom nekroza, a kroz nekoliko godina i slabljenje biljke i odumiranje, kao i nedostatak fosfora i željeza.

Ravnotežu u ishrani vinove loze, u ranijim istraživanjima, pokušalo se procijeniti na temelju graničnih vrijednosti opskrbljenosti lista vinove loze biogenim elementima i njihove raspoloživosti u tlu, dok se u novije vrijeme pokazalo da posebnu pozornost treba pokloniti up- 
ravo kationima, posebice kaliju, kalciju i magneziju te njihovom međusobnom odnosu (Ćosić i sur., 2010). Antagonizam i sinergizam često su prisutni u ishrani bilja pa je poznavanje odnosa među elementima osobito važno zbog održavanja fiziološke ravnoteže pojedinih elemenata u tlu i biljci (Fregoni, 2006) jer o njoj ovisi metabolizam kiselina, puferna sposobnost staničnog soka i pristupačnost mikroelemenata, osobito željeza i mangana, a osim toga autori navode da na kvalitetu grožđa, mošta i vina više utječe kationski odnos od pojedinog elementa (Fregoni, 2006; Čoga i sur., 2009; Ćosić i sur., 2010). Jedan od najpoznatijih antagonizama među hranivima kod vinove loze je antagonizam između kalija i kalcija te kalija i magnezija. Utvrđeno je da povećanje koncentracije kalija negativno utječe na usvajanje kalcija i magnezija (Freeman i Kliewer, 1983; Morris i sur., 1980, 1983; Christensen i sur., 1990), a Morris i sur. (1980) uočili su još i smanjene količine mangana u peteljkama. Poremećaj u odnosu kalij, kalcij i magnezij u zelenom tkivu loze, ponajprije peteljkovine nezreloga grozda, izaziva njezino sušenje - tzv. Stiellähme (Mirošević i Karoglan Kontić, 2008). U istraživanjima na sorti Sauvignon blanc, na vapnenom tlu, Petek i sur. (2008) navode da se smanjuje sadržaj fosfora i dušika prema kraju vegetacije, a povećava sadržaj kalcija i magnezija, dok su promjene u sadržaju kalija neznatne. Isti autori navode da se u skladu s tim mijenja i odnos $\mathrm{K} /(\mathrm{Ca}+\mathrm{Mg})$, koji je preširok u fenofazi cvatnje i pada prema kraju vegetacije, što autori dovode u vezu s nepovoljnim odnosom među kationima i smatraju da se može ispraviti primjenom magnezijevih gnojiva. Čoga i sur. (2009) ističu da se smanjuje dostupnost magnezija i kalija u vinovoj lozi na vapnenim tlima zbog antagonističkih odnosa između kalcija i magnezija kao i kalcija i kalija.

Cilj trogodišnjih istraživanja bio je utvrditi utjecaj reakcije tla na kationski odnos $\mathrm{K} /(\mathrm{Ca}+\mathrm{Mg})$ u lišću vinove loze kroz fenofaze rasta i razvoja (cvatnja, šara i berba).

\section{Materijali i metode}

Lokacije na kojima su postavljeni pokusi odabrane su na temelju preliminarnih rezultata istraživanja fizikalno-kemijskih svojstava tla na području Plešivičkog vinogorja (podregija Kontinentalne vinogradarske regije - sjeverozapadna Hrvatska). Istraživanja su provedena na tlima težeg mehaničkog sastava (praškasto glinasta ilovača i praškasta glina) i širokog raspona $\mathrm{pH}$ vrijednosti (lokacija Borička $\mathrm{pH}_{\mathrm{KCl}} 7,01$ - 7,41, a lokacija Rečki gaj $\mathrm{pH}_{\mathrm{KCl}}$ 3,54-5,01); količina ukupnog kalcija na lokaciji Borička kretala se od 103,17 do144,90 g Ca/kg, a na lokaciji Rečki gaj od 1,08 do $1,64 \mathrm{~g} \mathrm{Ca} / \mathrm{kg}$ (tablica 1).

Tablica 1. Kemijska svojstva tla, 2009.-2011. godina

Table 1. Chemical soil properties, year 2009-2011

\begin{tabular}{|c|c|c|c|c|c|c|c|}
\hline \multirow{2}{*}{$\begin{array}{l}\text { Parametar } \\
\text { Parameter }\end{array}$} & \multirow{2}{*}{$\begin{array}{c}\text { Dubina/ } \\
\text { Depth } \\
\text { (cm) }\end{array}$} & \multicolumn{2}{|c|}{ 2009. godina/year } & \multicolumn{2}{|c|}{ 2010. godina/year } & \multicolumn{2}{|c|}{ 2011. godina/year } \\
\hline & & Borička & Rečki gaj & Borička & Rečki gaj & Borička & Rečki gaj \\
\hline \multirow{2}{*}{$\mathrm{pH}_{\mathrm{H} 2 \mathrm{O}}$} & $0-30$ & $8,12-8,33$ & $4,92-5,83$ & $7,98-8,22$ & 4,59-5,82 & $7,90-8,26$ & 4,83-5,77 \\
\hline & $30-60$ & $8,14-8,32$ & $4,84-5,79$ & $7,95-8,28$ & $4,76-6,10$ & $8,01-8,33$ & $4,86-5,85$ \\
\hline \multirow{2}{*}{$\mathrm{pH}_{1 \mathrm{M} \mathrm{KCl}}$} & $0-30$ & $7,24-7,36$ & $3,54-4,48$ & $7,24-7,36$ & $3,62-5,01$ & $7,01-7,40$ & $3,68-4,53$ \\
\hline & $30-60$ & 7,27-7,41 & $3,64-4,40$ & $7,24-7,38$ & $3,69-5,01$ & $7,12-7,40$ & $3,74-4,79$ \\
\hline \multirow{2}{*}{$\begin{array}{l}\mathrm{CaO} \\
(\%)\end{array}$} & $0-30$ & $14,00-25,50$ & - & $15,00-25,50$ & - & $12,50-24,00$ & - \\
\hline & $30-60$ & $15,00-26,00$ & - & $15,50-26,00$ & - & $13,50-25,00$ & - \\
\hline $\mathrm{Ca}$ & $0-30$ & $107,90-141,78$ & $1,38-1,56$ & $106,70-143,05$ & 1,10-1,63 & $105,20-143,78$ & $1,41-1,70$ \\
\hline$\left(\mathrm{g} / \mathrm{kg}\left(\mathrm{uk}^{*}\right)\right)$ & $30-60$ & $107,90-143,77$ & $1,08-1,64$ & $108,08-144,90$ & $1,40-1,61$ & $103,17-144,72$ & $1,11-1,59$ \\
\hline $\mathrm{Mg}$ & $0-30$ & $9,12-10,87$ & $4,56-4,86$ & $9,18-10,90$ & $3,46-5,05$ & $9,02-10,52$ & $3,86-5,15$ \\
\hline$(g / k g(u k))$ & $30-60$ & $8,63-10,94$ & $3,65-5,04$ & $8,98-10,11$ & $4,21-50$ & $8,75-10,30$ & $3,27-5,12$ \\
\hline
\end{tabular}

*uk-ukupni/total 
Pokus je proveden u tri klimatski različite godine (2009.-2011.). U grafikonu 1 prikazan je odnos oborina i temperatura prema Walteru za Jastrebarsko za 2009. godinu iz kojeg je vidljiva mala količina oborina (u odnosu na temperaturu zraka) tijekom vegetacije uz lošu distribuciju (osim na prijelazu iz lipnja u srpanj). Ukupna količina oborina tijekom cijele 2009. godine iznosila je $939 \mathrm{~mm}$. Količina oborina tijekom vegetacijskog razdoblja iznosila je $511 \mathrm{~mm}$. Najmanje oborina zabilježeno je u svibnju $37 \mathrm{~mm}$, te u rujnu samo $26 \mathrm{~mm}$. U grafikonu 2 prikazan je odnos oborina i temperatura prema Walteru za Jastrebarsko za 2010. godinu. Jasno je vidljiva znatno veća količina oborina u odnosu na temperature zraka, osobito u mjesecu rujnu. Ukupna količina oborina u 2010. godini iznosila je $1380 \mathrm{~mm}$. U grafikonu 3 prikazan je odnos oborina i temperatura prema Walteru za Jastrebarsko za 2011. godinu. Vidljiva je znatno manja količina oborina u odnosu na temperature zraka, osobito u mjesecu svibnju, kolovozu i rujnu. Ukupna količina oborina tijekom cijele 2011. godine iznosila je samo $580 \mathrm{~mm}$. Prosječne vremenske prilike, prema raspodjeli percentila, u 2009. godini temperaturne prilike svrstavaju u kategoriju ekstremno toplo vrijeme za područje Plešivice, a oborinske prilike u kategoriju normalno. Godina 2010. temperaturno je svrstana u kategoriju toplog vremena, a oborinski u kategoriju vrlo kišno, dok je 2011. godina kategorizirana kao ekstremno topla i ekstremno sušna za područje Plešivice (DHMZ).

Grafikon 1. Walterov klima dijagram za meteorološku postaju Jastrebarsko za 2009. godinu Graph 1. Walter's climate diagram for the meteorological station Jastrebarsko for 2009

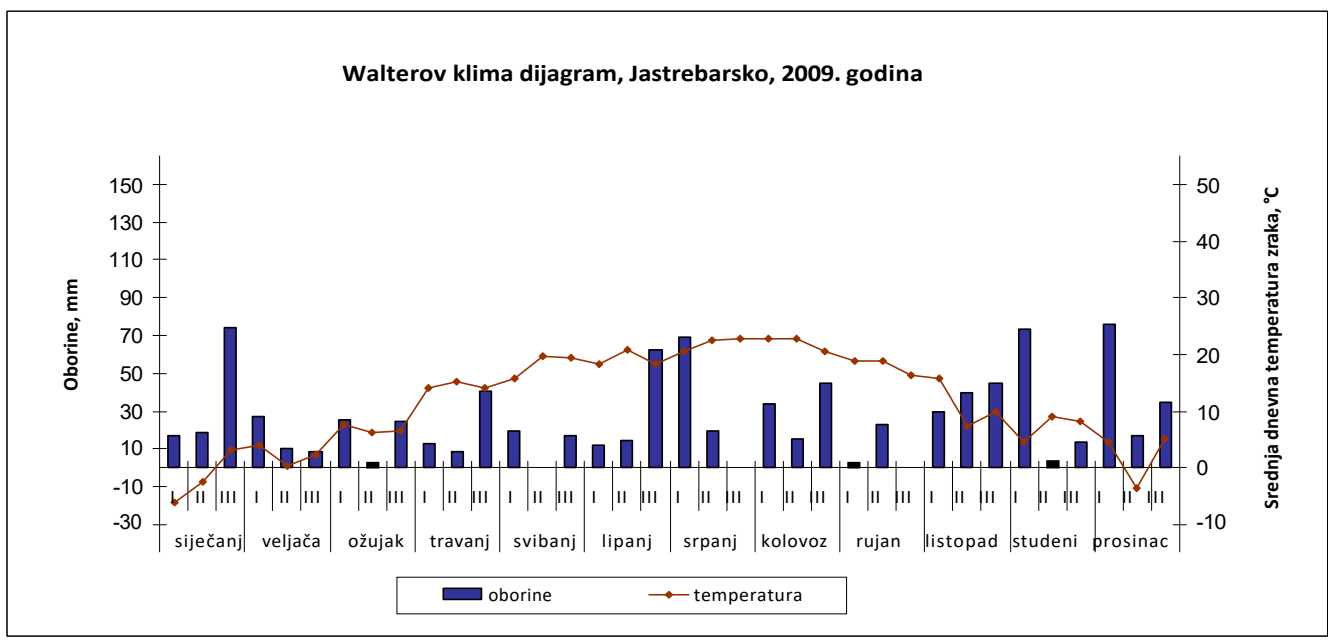


Grafikon 2. Walterov klima dijagram za meteorološku postaju Jastrebarsko za 2010. godinu Graph 2. Walter's climate diagram for the meteorological station Jastrebarsko for 2010

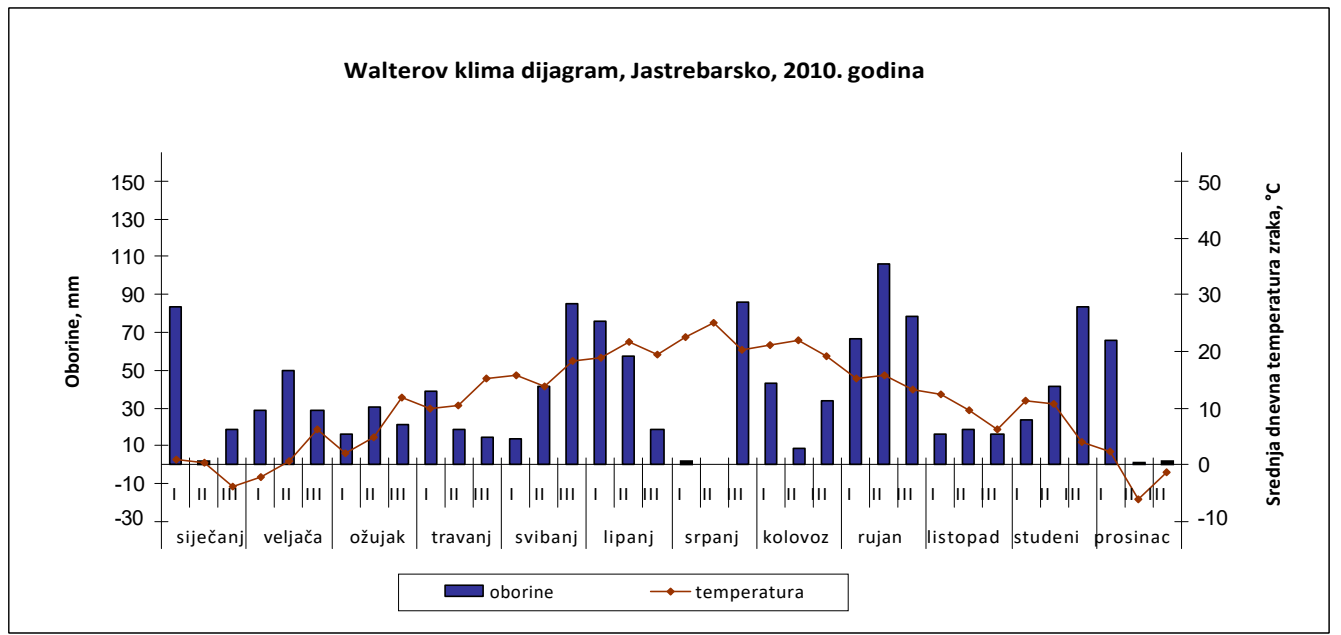

Grafikon 3. Walterov klima dijagram za meteorološku postaju Jastrebarsko za 2011. godinu Graph 3. Walter's climate diagram for the meteorological station Jastrebarsko for 2011

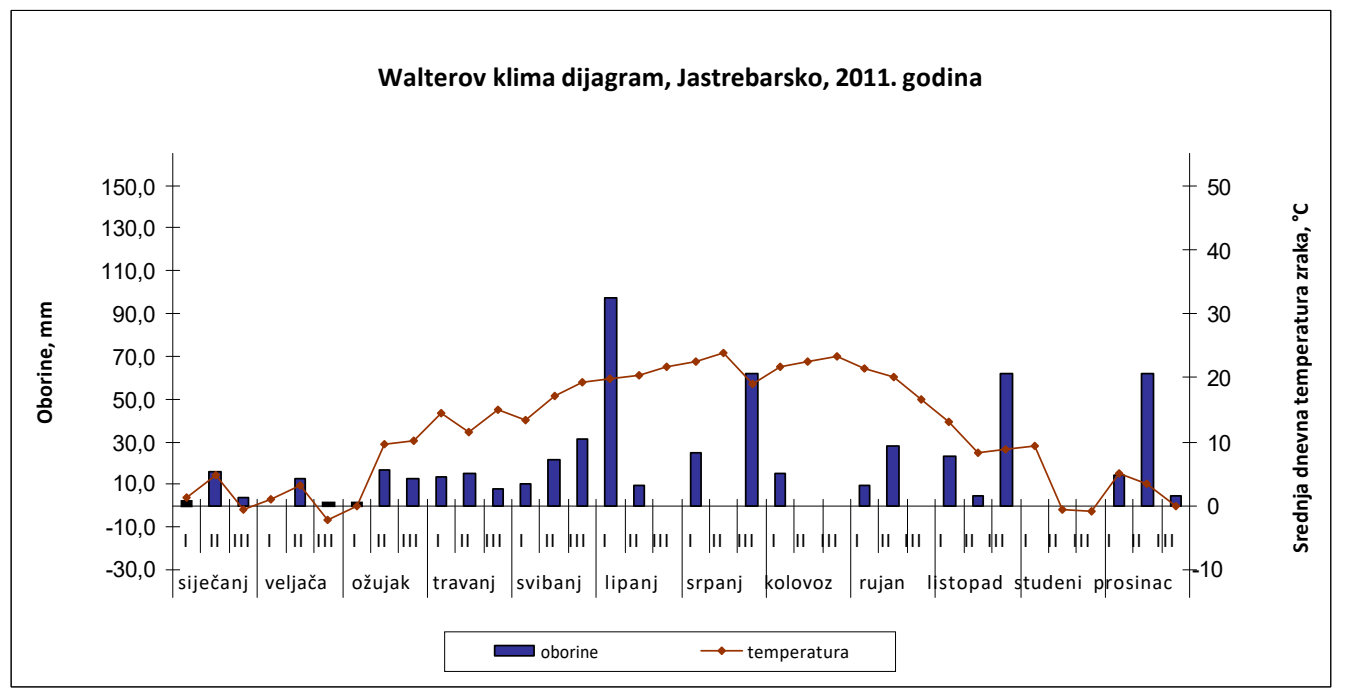

Na obje lokacije formirano je 9 pokusnih parcela s 2 reda po 20 trsova. Sorta loze u istraživanju bila je Sauvignon bijeli (Muškatni silvanac) na podlozi Berlanderieri x Riparia (SO4). Uzorci tla uzeti su sa dvije dubine 0-30 i 30-60 cm na obje lokacije (Borička i Rečki gaj) na početku vegetacije u sve tri godine, a rezultati kemijske analize tla nisu pokazali značajne razlike u pH vrijednosti tla, kao ni u koncentraciji fiziološki aktivnog kalija u tlu, koncentraciji zamjenjivog aluminija (lokacija Rečki gaj) i fiziološki aktivnog vapna (lokacija Borička) u godinama istraživanja (2009.-2011.). Za analizu biljnog materijala uzimani su uzorci lišća tri (3) puta tijekom vegetaci- 
je: u punoj cvatnji, šari i u berbi. Prosječni uzorak biljnog materijala na svim pokusnim parcelicama formiran je od 80 zdravih, potpuno razvijenih i neoštećenih listova uzetih na rodnoj rozgvi, nasuprot grozdova sa svih 40 trsova (2 lista po trsu) od kojih se sastojala jedna pokusna parcela. U uzorcima lišća vinove loze (za sva 3 uzorkovanja) određene su količine kalija, kalcija i magnezija (nakon digestije s koncentriranom $\mathrm{HNO}_{3}$ (MILESTONE 1200 Mega Microwave Digester). Kalij je određen plamenfotometrijski (AOAC, 1995), dok su kalcij i magnezij određeni AASom). Nakon utvrđenih koncentracija kalija, kalcija i magnezija u lišću vinove loze, kationski odnos je dobiven računski. Koncentracija kalija, kalcija i magnezija u biljnom materijalu praćena je u ovisnosti o reakciji tla i vremenu uzorkovanja.

Statistički model kojim se nastojalo predvidjeti kretanje istih u listu uključio je, prema tome, reakciju tla svake pokusne parcele i vrijeme uzorkovanja kao nezavisne varijable. Statistička analiza podataka provedena je primjenom statističkog programskog paketa SAS (SAS Institute Inc., 2007).

\section{Rezultati i rasprava}

Rezultati analize varijance za kationski odnos $\mathrm{K} /(\mathrm{Ca}+\mathrm{Mg})$ u suhoj tvari lišća vinove loze tijekom tri godine istraživanja prikazani su u tablici 2. Iz tablice ANOVA-e vidljivo je da je značajan utjecaj na kationski odnos u lišću vinove loze u sve tri godine istraživanja imala pH vrijednost tla te fenofaza rasta i razvoja, a utvrđena je i značajna interakcija fenofaze razvoja i pH vrijednosti tla.

Tablica 2. Rezultati analize varijance za kationski odnos $\mathrm{K} /(\mathrm{Ca}+\mathrm{Mg})$ u lišću vinove loze, 2009.-2011. godina

Table 2. Results of the analysis of variance for the cation ratio $\mathrm{K} /(\mathrm{Ca}+\mathrm{Mg})$ in grapevine leaf, years 2009-2011

\begin{tabular}{lcccc}
\hline & 2009. godina & Year 2009 & $\begin{array}{c}\text { 2010. godina } \\
\text { Year 2010 }\end{array}$ & $\begin{array}{c}\text { 2011. godina } \\
\text { Year 2011 }\end{array}$ \\
\hline $\begin{array}{l}\text { tzvor varijabithosti } \\
\text { Source of variability }\end{array}$ & DF & Pr $>\mathrm{F}$ & $\operatorname{Pr}>\mathrm{F}$ & $\mathrm{Pr}>\mathrm{F}$ \\
\hline $\mathrm{pH}$ & 1 & $<, 0001$ & $<, 0001$ & $<, 0001$ \\
\hline Fenofaza (Phenophase) & 2 & $<, 0001$ & $<, 0001$ & $<, 0001$ \\
\hline pH x fenofaza (pH x phenophase) & 2 & 0,0001 & 0,0116 & $<, 0001$ \\
\hline Pogreška (Error) & 48 & & & \\
\hline
\end{tabular}

U tablici 3 prikazane su srednje vrijednosti kationskog odnosa u suhoj tvari lišća vinove loze tijekom istraživanja (2009.-2011. godina). Značajno širi prosječni odnos $\mathrm{K} /(\mathrm{Ca}+\mathrm{Mg}) \mathrm{u}$ lišću vinove loze, utvrđen je na kiselom tlu $(0,29 ; 0,58 ; 0,59)$ u odnosu na alkalno tlo $(0,20 ; 0,40 ; 0,38)$. Najuži odnos $(0,10)$ u lišću utvrđen je u fenofazi šare na alkalnom tlu u 2009. godini (godina sa normalnom količinom oborina pa je usvajanje kalcija i magnezija bilo puno bolje u odnosu na 2010. i 2011. godinu) dok je najširi odnos $\mathrm{K} /(\mathrm{Ca}+\mathrm{Mg})$ u lišću $(1,41)$ utvrđen u 2011. godini u fenofazi cvatnje na kiselom tlu. Do ovako širokog i nepovoljnog odnosa došlo je vjerojatno zato što je 2011. godina bila ekstremno suha što je rezultiralo smanjenim usvajanjem kalcija i magnezija (u biljci se usvajaju masovnim strujanjem (Vukadinović i Vukadinović, 2016.)), te zbog činjenice da su koncentracije ukupnog kalcija i magnezija bile značajno veće na alkalnom tlu u odnosu na kiselo tlo. Različite kemijske i fizikalne karakteristike tla te klimatski uvjeti, nedvojbeno su utjecali na dinamiku usvajanja hraniva u vinovoj lozi, a potrebno je spomenuti i antagonizam koji postoji između kalija i kalcija te kalija i magnezija. 
Statistički značajno najširi $\mathrm{K} /(\mathrm{Ca}+\mathrm{Mg})$ odnos u lišću vinove loze u 2009. godini (tablica 4), na kiselom i na alkalnom tlu, utvrđen je u fenofazi cvatnje $(0,39)$ i značajno se razlikuje $(P \leq 5 \%)$ od odnosa u fenofazama šare i berbe koje se međusobno nisu razlikovale. U 2010. i 2011. godini kationski odnos (tablica 4) u lišću vinove loze u sve tri fenofaze, značajno se razlikuje ( $\mathrm{P} \leq 5 \%$ ). Značajno najširi odnos $\mathrm{K} /(\mathrm{Ca}+\mathrm{Mg}) \mathrm{u}$ listu vinove loze i na kiselom i alkalnom tlu, utvrđen je $u$ fenofazi cvatnje $(0,73$ i 0,78$)$, a najuži u fenofazi berbe $(0,28$ i 0,27$)$.

Prema Fregoni (2006) optimalni odnos za K/(Ca+Mg) u listu vinove loze je 0,30-0,40, a nisu poželjni niti preširoki niti uži odnosi od optimalnih jer može doći do nedostatka ili suviška nekog hraniva. Uspoređujući utvrđeni kationski odnos u lišću vinove loze s optimalnim vrijednostima, vidljivo je da varira u ovisnosti o godini i o fenofazi rasta i razvoja.

Optimalan $\mathrm{K} /(\mathrm{Ca}+\mathrm{Mg})$ odnos utvrđen je samo u fenofazi cvatnje $(0,39)$ u 2009. i u fenofazi šare $(0,40)$ u 2011. godini (prosjeci odnosa za kiselo i alkalno tlo). U ostalim fenofazama odnos je poremećen pa je tako u 2009. godini u fenofazama šare i berbe $(0,16 ; 0,18)$ te u 2010. i 2011. godini u fenofazi berbe $(0,28 ; 0,27), \mathrm{K} /(\mathrm{Ca}+\mathrm{Mg})$ odnos ispod optimalnog, neovisno o reakciji tla. U fenofazi cvatnje u 2010. i 2011. godini (odnos 0,73, 0,78) i u fenofazi šare u 2010. godini $(0,46)$ $\mathrm{K} /(\mathrm{Ca}+\mathrm{Mg}$ ) odnos $\mathrm{u}$ lišću vinove loze bio je preširok (na kiselom i na alkalnom tlu). Utvrđene razlike $\mathrm{u}$ odnosu $\mathrm{K} /(\mathrm{Ca}+\mathrm{Mg})$ među pojedinim fenofazama očekivane su ukoliko se ima na umu činjenica da vrijednosti kalija prema kraju vegetacije postupno opadaju, a vrijednosti kalcija i magnezija rastu.

Regresijskom analizom utvrđeno je da odnos $\mathrm{K} /(\mathrm{Ca}+\mathrm{Mg})$ u lišću vinove loze tijekom sve tri godine istraživanja (grafikon 4, 5 i 6) neznatno pada za sve tri fenofaze rasta (cvatnja, šara, berba) ako je $\mathrm{pH}$ vrijednost u tlu veća za jediničnu vrijednost (u 2009. godini $r=-0,0505 ;-0,0164$ i $-0,015$, u 2010. godini $r=-0,0948,-0,0467 \mathrm{i}-0,0425$ i u 2011. godini $r=-0,1551,-0,0261 \mathrm{i}-0,0222)$.

Najširi K/(Ca+Mg) odnos u lišću vinove loze utvrđen je u fenofazi cvatnje neovisno o reakciji tla, a sve je uži prema kraju vegetacije osobito na alkalnom tlu. Rezultati utvrđeni u ovom istraživanju sukladni su navodima drugih autora - Čoga i sur. (2009) navode da se odnos $\mathrm{K} /(\mathrm{Ca}+\mathrm{Mg})$ kretao od 0,38 do 0,77 u fenofazi cvatnje, a u fenofazi berbe od 0,12 do 0,27; a Slunjski i sur. (2011) su utvrdili da je odnos u fenofazi cvatnje bio 0,35 do 0,83, u fenofazi berbe 0,18 do 0,31. Petek i sur. (2008.) također su utvrdili da je najširi K/(Ca+Mg) odnos u cvatnji $(0,73)$, a najuži u berbi $(0,25)$.

Tablica 3. Kationski odnos $\mathrm{K} /(\mathrm{Ca}+\mathrm{Mg})$ u listu vinove loze, 2009.-2011. godina

Table 3. Cation ratio $\mathrm{K} /(\mathrm{Ca}+\mathrm{Mg})$ in grapevine leaf, years $2009-2011$

\begin{tabular}{|c|c|c|c|c|c|c|c|c|c|c|c|}
\hline \multirow[b]{2}{*}{$\begin{array}{l}\text { Tlo } \\
\text { Soil }\end{array}$} & \multirow[b]{2}{*}{$\begin{array}{c}\mathrm{pH} \\
1 \mathrm{MKCl}\end{array}$} & \multirow[b]{2}{*}{$\begin{array}{c}\text { Fenofaza } \\
\text { Phenophase }\end{array}$} & \multicolumn{3}{|c|}{$\begin{array}{c}\text { 2009.godina } \\
\text { Year2009 }\end{array}$} & \multicolumn{3}{|c|}{$\begin{array}{c}\text { 2010.godina } \\
\text { Year2010 }\end{array}$} & \multicolumn{3}{|c|}{$\begin{array}{l}\text { 2011.godina } \\
\text { Year2011 }\end{array}$} \\
\hline & & & Min & Max & $\begin{array}{l}\text { Prosjek } \\
\text { Average }\end{array}$ & Min & Max & $\begin{array}{l}\text { Prosjek } \\
\text { Average }\end{array}$ & Min & Max & $\begin{array}{l}\text { 'rosjek } \\
\text { Average }\end{array}$ \\
\hline \multirow{3}{*}{$\begin{array}{l}\text { Kiselotlo } \\
\text { Acidicsoil }\end{array}$} & \multirow{3}{*}{$3,54-5,01$} & $\begin{array}{l}\text { Cvatnja } \\
\text { Flowering }\end{array}$ & 0,34 & 0,60 & 0,48 & 0,64 & 1,13 & 0,87 & 0,83 & 1,41 & 1,02 \\
\hline & & $\begin{array}{c}\text { Sara } \\
\text { Veraison }\end{array}$ & 0,14 & 0,24 & 0,19 & 0,50 & 0,66 & 0,54 & 0,34 & 0,56 & 0,43 \\
\hline & & $\begin{array}{l}\text { Berba } \\
\text { Harvest }\end{array}$ & 0,17 & 0,25 & 0,21 & 0,24 & 0,45 & 0,34 & 0,27 & 0,37 & 0,31 \\
\hline & $\begin{array}{r}\text { Prosjek } \\
\text { Average } \\
\end{array}$ & & 0,22 & 0,36 & 0,29 & 0,46 & 0,75 & 0,58 & 0,48 & 0,78 & 0,59 \\
\hline \multirow{3}{*}{$\begin{array}{l}\text { Alkalnotlo } \\
\text { Alkalinesoil }\end{array}$} & \multirow{3}{*}{$7,01-7,41$} & $\begin{array}{l}\text { Cvatnja } \\
\text { Flowering }\end{array}$ & 0,25 & 0,36 & 0,31 & 0,47 & 0,72 & 0,59 & 0,36 & 0,81 & 0,54 \\
\hline & & $\begin{array}{c}\text { Šara } \\
\text { Veraison }\end{array}$ & 0,10 & 0,22 & 0,14 & 0,29 & 0,48 & 0,38 & 0,27 & 0,43 & 0,36 \\
\hline & & $\begin{array}{c}\text { Berba } \\
\text { Harvest }\end{array}$ & 0,11 & 0,19 & 0,15 & 0,16 & 0,32 & 0,22 & 0,16 & 0,28 & 0,24 \\
\hline & $\begin{array}{l}\text { Prosjek } \\
\text { Average }\end{array}$ & & 0,15 & 0,26 & 0,20 & 0,31 & 0,51 & 0,40 & 0,26 & 0,51 & 0,38 \\
\hline
\end{tabular}


glasnik zaštite bilja $\begin{gathered}64 \\ \text { godine }\end{gathered}$

Tablica 4. Usporedbe prosjeka pojedinih uzorkovanja za K/(Ca+Mg), 2009.-2011. godina

Table 4. Comparison of mean values of samplings for $\mathrm{K} /(\mathrm{Ca}+\mathrm{Mg})$, year 2009-2011

\begin{tabular}{lccc}
\hline $\begin{array}{l}\text { Uzorkovanje } \\
\text { Sampling }\end{array}$ & $\begin{array}{c}\text { 2009. godina } \\
\text { Year 2009 }\end{array}$ & $\begin{array}{c}\text { 2010. godina } \\
\text { Year 2010 }\end{array}$ & $\begin{array}{c}\text { 2011. godina } \\
\text { Year 2011 }\end{array}$ \\
\hline 1 (Cvatnja) (Flowering) & $0,39 \mathrm{a}$ & $0,73 \mathrm{a}$ & $0,78 \mathrm{a}$ \\
\hline 2 (Šara) (Veraison) & $0,16 \mathrm{~b}$ & $0,46 \mathrm{~b}$ & $0,40 \mathrm{~b}$ \\
\hline 3 (Berba) (Harvest) & $0,18 \mathrm{~b}$ & $0,28 \mathrm{c}$ & $0,27 \mathrm{c}$ \\
\hline
\end{tabular}

RazličitaslovapredstavljajuznačajnorazličitevrijednostipremaBonferronijevomtestu, $P \leq 0,05$ Different letters represents significantly different values according to Bonferroni test, $\mathrm{P} \leq 0,05$

Grafikon 4. Utjecaj reakcije tla na dinamiku K/(Ca+Mg) u lišću vinove loze u 2009. godini Graph 4. Effect of soil reaction on dynamics K/(Ca+Mg) in grapevine leaf in yrae 2009

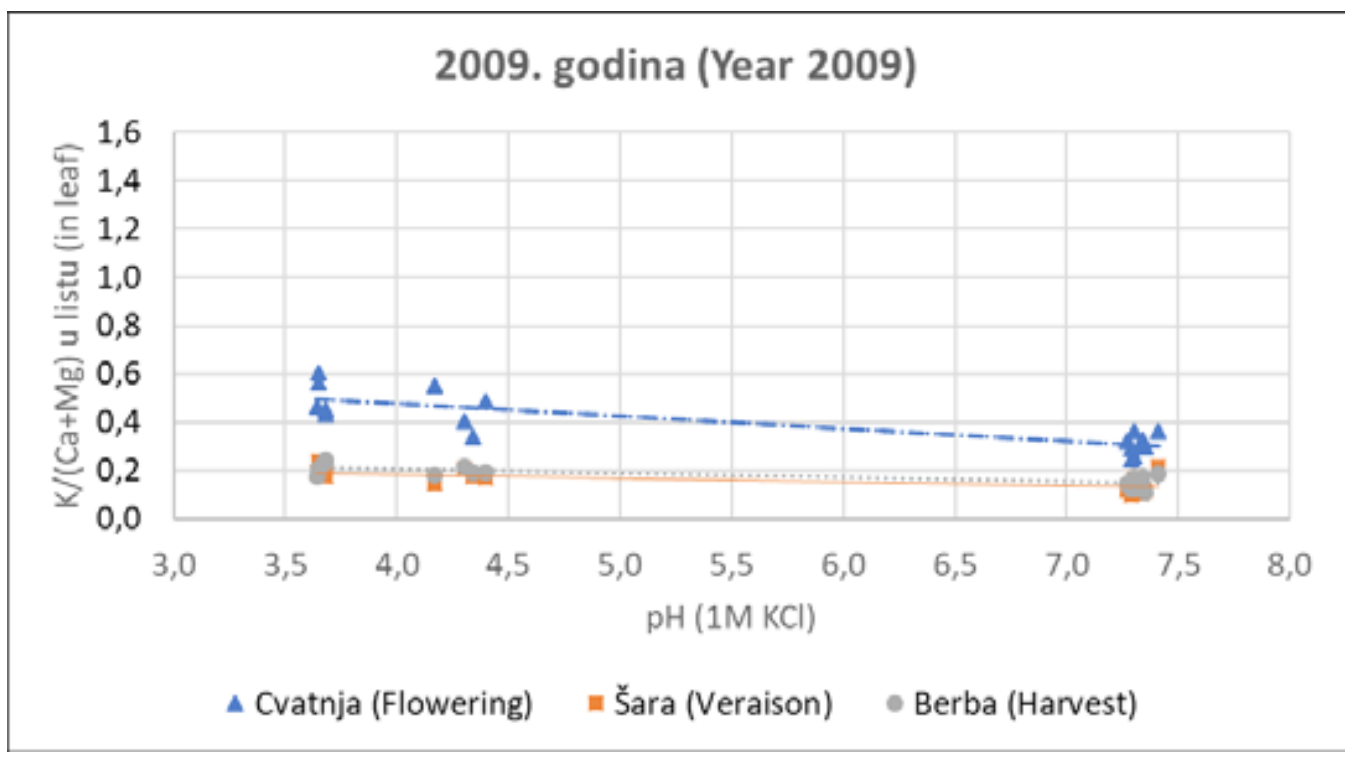


Grafikon 5. Utjecaj reakcije tla na dinamiku K/(Ca+Mg) u lišću vinove loze u 2010. godini Graph 5. Effect of soil reaction on dynamics $\mathrm{K} /(\mathrm{Ca}+\mathrm{Mg})$ in grapevine leaf in yrae 2010

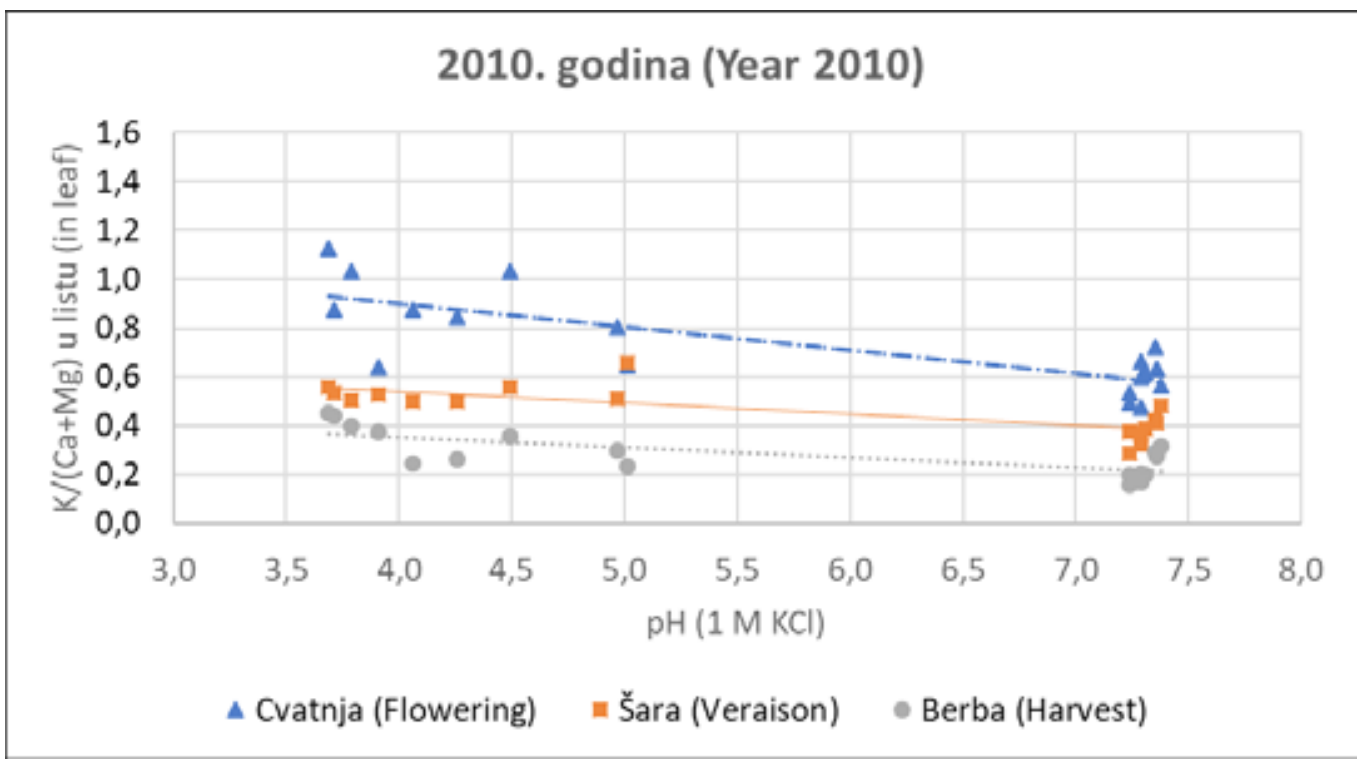

Grafikon 6. Utjecaj reakcije tla na dinamiku K/(Ca+Mg) u lišću vinove loze u 2011. godini Graph 6. Effect of soil reaction on dynamics $\mathrm{K} /(\mathrm{Ca}+\mathrm{Mg})$ in grapevine leaf in year 2011

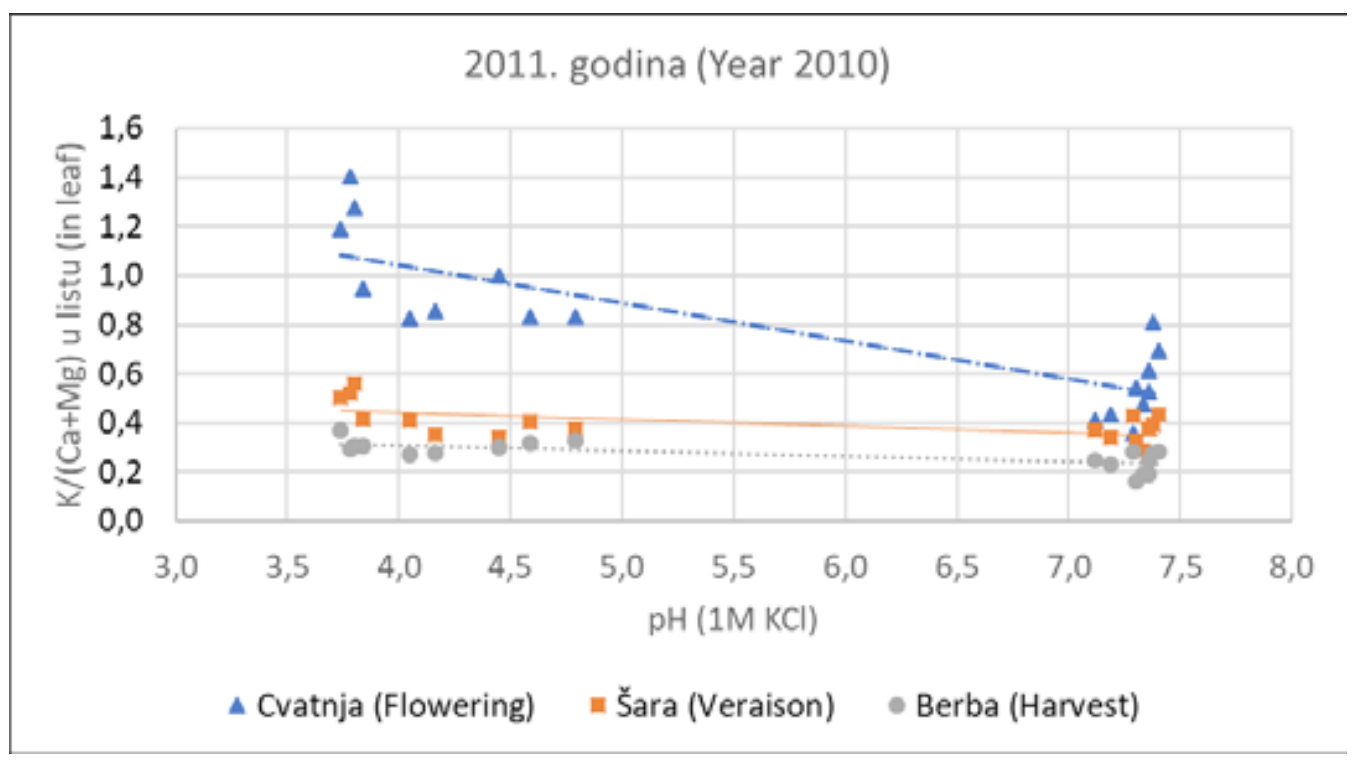




\section{Zaključci}

U sve tri godine istraživanja utvrđen je značajan utjecaj reakcije tla, fenofaze i interakcijski učinak reakcije tla i fenofaze na kationski odnos $\mathrm{K} /(\mathrm{Ca}+\mathrm{Mg})$. Širi prosječni odnos $\mathrm{K} /(\mathrm{Ca}+\mathrm{Mg}) \mathrm{u}$ lišću vinove loze utvrđen je na kiselom tlu $(0,29-0,59)$ u odnosu na alkalno tlo $(0,20-0,40)$.

Utvrđeni odnos $\mathrm{K} /(\mathrm{Ca}+\mathrm{Mg})$ po fenofazama, neovisno o reakciji tla, najširi je u fenofazi cvatnje $(0,31-1,02)$ i sužava se prema berbi $(0,15-0,34)$ u svim godinama istraživanja.

U Hrvatskoj je značajan dio vinograda podignut upravo na kiselim i alkalnim tlima pa provedeno istraživanje doprinosi boljem upoznavanu usvajanja i dinamike kalija, kalcija i magnezija te njihovog međusobnog odnosa u lišću vinove loze na kiselom i alkalnom tlu. Dobiveni rezultati mogu biti pokazatelj kako gnojidbom djelovati na ishranu vinove loze da bi se dobili što bolji međuodnosi kationa na tlima različitih pH vrijednosti, uvažavajući pri tome i klimatske prilike koje su posljednjih godina sve ekstremnije.

\section{Literatura}

Al-Obeed, R.S., Kassem, H.A., Ahmed, A. (2011). Leaf petiole mineral and fruit heavy metals content of different grape cultivars grown under arid environments and irrigated with treated domestic wastewater. AAB Bioflux. 3/1:5-14. http://www.aab.bioflux.com.ro

AOAC (1995). Officinal Method of Analysis of AOAC International. 16th Edition, Vol. I. Arlington, USA.

Bergmann, W. (1992). Nutritional Disorders of Plants. Gustav Fischer Verlag Jena, Stuttgart, New York.

Christensen, L.P., Boggero, J., Bianchi, M. (1990). Comparative leaf tissue analysis of potassium deficiency and a disorder resembling potassium deficiency in Thompson Seedless grapevines. American Journal of Enology and Viticulture, 41:77-83. https://www.ajevonline.org/content/41/1/77

Čoga, L., Slunjski, S., Herak Ćustić, M., Maslać, J., Petek, M., Ćosić, T., Pavlović, I. (2009). Influence of Soil Reaction on Phosphorus, Potassium, Calcium and Magnesium Dynamics in Grapevine (Vitis vinifera L.). Agriculturae Conspectus Scientificus. 74(1):1-16. https://hrcak.srce.hr/35775

Ćosić, T., Karažija, T., Čoga, L., Petek, M., Poljak, M., Herak Ćustić, M., Jurkić, V., Pavlović, I., Slunjski, S. (2010). Istraživanje biljno hranidbenog kapaciteta vinograda u Bolu folijarnom analizom. Studija Zavoda za ishranu bilja. Zagreb.

DHMZ - Državni hidrometeorološki zavod, http:/klima.hr/ocjene-arhiva.php.

Freeman, B.M., Kliewer, W.M. (1983). Effect of irrigation, crop level and potassium fertilization on Carignane vines. II. Grape and wine quality. American Journal of Enology and Viticulture, 34, 197-207. https://www.ajevonline.org/content/34/3/197

Fregoni, M. (2006). Viticoltura di qualita. Tecniche nuove, Milano, Italy.

Gluhić, D., Herak Ćustić, M., Petek, M., Čoga, L., Slunjski, S., Sinčić, M. (2009). The Content of Mg, K and Ca lons in Vine Leaf under Foliar Application of Magnesium on Calcareous Soils. Agriculturae Conspectus Scientificus. 74(2):8184.https://hrcak.srce.hr/39336

Herak Ćustić, M., Čoga, L., Ćosić, T., Petek, M., Poljak, M., Jurkić, V., Pavlović, I., Ljubičić, M., Ćustić, S. (2005). Reakcija tla-bitan preduvjet za odabir bilja u hortikulturi. Agronomski glasnik, 67(2-4):235-253. https://hrcak.srce.hr/2242

Kovačević, V., Bertić, B., Grgić, D. (1993). Response of Maize, Barley, Wheat and Soybean to Liming on Acid Soils. Rostlinna Vyroba 39 (1),41-52.

Mirošević, N., Karoglan Kontić J. (2008). Vinogradarstvo, Nakladni zavod Globus, Zagreb.

Morris, J.B., Cawthon, D.L., Fleming, J.W. (1980). Effects of High Rates of Potassium Fertilization on Raw Products Quality and Change in $\mathrm{pH}$ and Acidity During Storage of Concord Grape Juice. American Journal of Enolology and Viticulture. 31(4):323-328. https://www.ajevonline.org/content/31/4/323.short

Olmo, P.H. (2000). The origin and Domestication of the Vinifera Grape. In: The Origins and Ancient History of Wine, eds. McGovern E. Patric, Fleming J.

Pejić, I., Maletić, E. (2013). Istraživanje genetskih resursa vinove loze na području Rudine (Psunj). Radovi za znanstveni i umjetnički rad u Požegi. 2:175-185. https://hrcak.srce.hr/109874

Petek, M., Gluhić, D., Herak Ćustić, M., Čoga, L., Ćosić, T., Slunjski, S. (2008). Leaf content of macro and microelements in Vitis vinifera cv. Sauvignon Blanc. VII SHS International Symposium on Mineral Nutrition of Fruit Crops. Book of Abstracts. Faro, Portugal, pp 35. https://www.bib.irb.hr/471323

SAS Institute Inc. (2007). SAS/STAT User's Guide. SAS Institute Inc., Cary, NC

Slunjski, S., Čoga, L., Pavlović, I., Jurkić, V., Herak Ćustić, M., Petek, M., Ćosić, T. (2011). Dinamika kalija u lišću vinove loze na kiselim i karbonatnim tlima. Zbornik radova 46. hrvatskog i 6. međunarodnog simpozija agronoma, $165-168$. https://www.bib.irb.hr/520111

Vukadinović, V., Vukadinović, V. (2016). Tlo, gnojidba, prinos. e-izdanje, Osijek.

Prispjelo/Received: 28.4.2020.

Prihvaćeno/Accepted: 5.10.2020. 


\title{
Effect of soil pH on cation ratio in grapevine (Vitis vinifera L.) leaf
}

\begin{abstract}
Soil reaction is one of the most important factors that affects solubility and availability of nutrients to plants. The aim of the present research was to determine the effect of soil reaction on the $\mathrm{K} /(\mathrm{Ca}+\mathrm{Mg})$ ratio in the grapevine (Vitis vinifera L.) leaves of the cultivar Sauvignon Blanc (rootstock SO4) in the Plešivica wine growing region (Northwest Croatia). The research was conducted in the period 2009-2011 in the Plešivica wine growing region on very acid to acid soil (location Rečki gaj: $\left.\mathrm{pH}_{\kappa c l} 3,54-5,01\right)$ and on alkaline soil (location Borička: $\mathrm{pH}_{\mathrm{KCl}}$ 7,01-7,41). Leaves samples for monitoring the dynamics of potassium, calcium and magnesium and their mutual relationship, have been taken each year three times during vegetation (in the following phenological stages: flowering, veraison and harvest). A significant effect on the $\mathrm{K} /(\mathrm{Ca}+\mathrm{Mg})$ ratio in the grapevine leaves was determined in respect to soil reaction and the phenological stage in all three years of research. The wider ratio of $\mathrm{K} /(\mathrm{Ca}+\mathrm{Mg})$ in the leaves in all three years was determined on the acidic soil $(0.29,0.58,0.59)$ in respect to alkaline soil $(0.20,0.40,0.38)$. The widest cation ratio was determined in the stage of flowering (0.31-1.02) while the most limited ratio was determined in the stage of harvest (0.15-0.34) in all research years regardless soil reaction.
\end{abstract}

Keywords: flowering, harvest, $\mathrm{K} /(\mathrm{Ca}+\mathrm{Mg}), \mathrm{pH}$ value, veraison

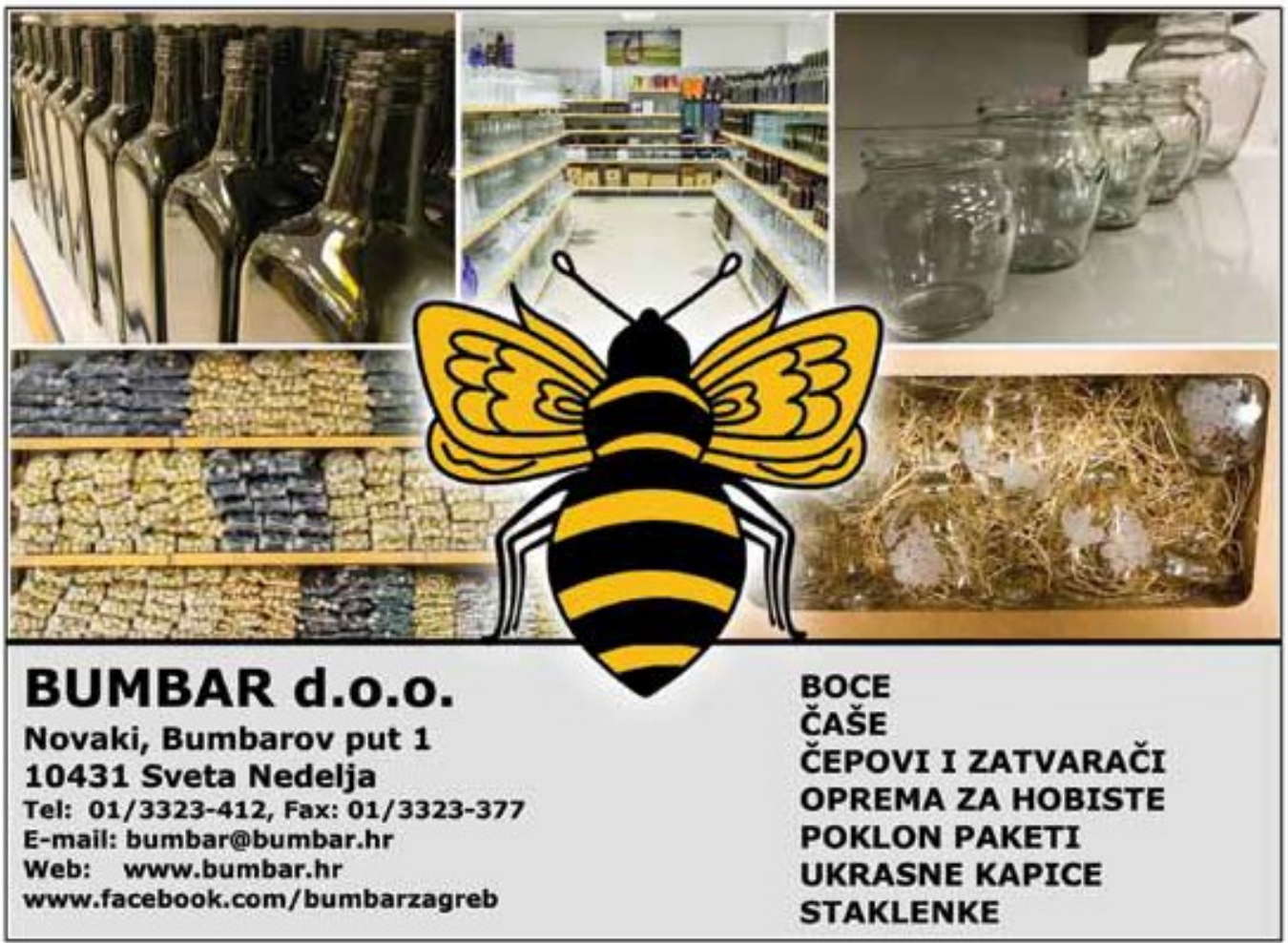

